\title{
Propaganda, critical media literacy and participation: Tracing memories of the Soviet media
}

\author{
Natalija Mažeikienè ${ }^{1}$ \\ Kristina Juraité2 \\ Department of Public Communications, Vytautas Magnus University, Lithuania
}

\section{doi:10.5937/comman1430089M}

Summary: The role of media is crucial in promoting the public sphere and determining the forms of civic participation. In the post-Soviet context, the relationship between media audiences and the legacy of propaganda-driven media is of particular importance from the perspectives of media history and democratic development. The post-Soviet media environment was shaped by particular political traditions and notions of citizenship. The Soviet mass media was subordinated to the state ideology as its main instrument, enabling the state authorities to impose their propaganda and keep control over the population. On the other hand, contemporary civil cultures and active public participation is being shaped by citizens' memories of their media practices then and now. Effective civic participation can only be realized by developing critical reflection towards the past, identifying and articulating personal perspectives towards the propaganda and its effect on the citizens' societal participation. The main aim of the article is to explore the relationship between democratic participation and critical media literacy. We underscore media literacy in Lithuania began developing well before the democratic transition that took off in the late 1980s; moreover, today we see what is termed as a process of democratization of memory of the Soviet past. Oral history research shows that citizens express well-defined critiques of the power manipulation and propaganda persuasion in the media during the Soviet era. Reconstructions of the individual strategies of watching Soviet television in the past and comparing them to the present practices reveal critical media literacy skills as an important prerequisite for democratic and deliberative participation.

Keywords: critical media literacy, participation, Soviet propaganda, democratic habitus, democracy of memory, politics of memory, Soviet television, oral history

\footnotetext{
1 n.mazeikiene@adm.vdu.lt

2 k.juraite@pmdf.vdu.lt
} 


\section{Introduction}

At the beginning of the Second World War, Lithuania was occupied by the USSR, initiating a Soviet era that lasted half a century. In this period, an authoritarian regime was in place, which did not leave much space for democracy or participation. The Soviet media system was subordinated to the state ideology, becoming its main instrument and enabling the state authorities to impose its propaganda and political control over the population. People were pumped with positive information about labour achievements and victories, but rarely informed on critical public issues like drugs, prostitution, mafia, unemployment, accidents, ethnic clashes, environmental risks, etc. These issues that actually worried people were "nonexistent" in the Soviet media.

The development of television in Lithuania began as late as 1957, after the Soviet authorities in Moscow took the decision to expand television broadcasting and build a local television network. By the beginning of television broadcasting in Lithuania, there were 0.6 television receivers per 1,000 inhabitants. Television could hardly compete with other media, such as radio and the press until 1980s, when domestic television sets increased to over 300 per 1,000 inhabitants and television became the main source of news and information for the Soviet audience (Hoyer et al., 1993: 357; McNair, 1991: 40). From the very beginning television broadcastings were under stringent supervision of the communist party's leadership. Any kind of independent, unauthorized or critical activity was severely punished. No freedom of speech, no objectivity, no pluralism were the defining characteristics of the Soviet media, especially before 1985. Together with the glastnost and perestroika campaigns launched by Gorbachev in 1985, the freedom of expression in the mainstream media made some gains, and television production became more open, diverse and attractive. However, pluralism and democratization could not be achieved straightaway.

This also had its impact on the contemporary era. Sovietologists and political researchers have argued that in post-communist societies individual and collective habitus and political values, as well the relationship between the citizens, the state and other institutions inherited from the Soviet system, have persisted in terms of a passive political culture and a paternalistic perception of the state by its citizens (Verdery, 2002; Rose, 2009). This can also be found in Lithuania, where despite over 20 years of liberal democracy, market economy and free media, political participation has been among the lowest in the EU (European 
Commission, 2013). Lithuania has been one of the most sceptical among the European countries with regard to political participation, trust in political institutions and citizens' engagement in public life (European Commission, 2013). This means that the democratic transition does not by itself guarantee increased political activism or enlightened political discourse. Even though democratic structures and institutions, such as free elections and independent media, are of crucial importance, the democratizing potential of these institutions depends on other factors, namely socio-cultural, political and economic structures that have been developing for decades, if not centuries (Papacharissi, 2002; Schudson, 2003).

In the post-Soviet context, propaganda-driven media have disappeared, replaced by a neo-liberal media market. To ensure media freedom and pluralism, a rather liberal legislative framework and professional standards have been adopted, following the Western democratic media model (Juraite, 2008; Balčytienè, 2006). However, the processes of privatization and liberalization have led to an increase in commercialization, combined with a lack of professionalism and social responsibility. Popular media content has gained a strong presence, to the detriment of information focussed on the public interest, such as news programs, political talk shows, analytical programs and documentaries (Balčytienè and Juraite, 2009). Nevertheless, media can still (at least potentially) play a crucial role in promoting the public sphere and determining the forms of civic participation. People can participate "in the media", but citizens can also participate in society more broadly "via the media" (Carpentier, 2011). Participation is a complex and multi-layered concept that is closely connected, but still different from a series of other concepts, which act as its conditions of possibility. Carpentier (2011) mentions access and interaction as pre-requisites, while Dahlgren (2009) refers to civic cultures. Carpentier, Schrøder and Hallett (2014: 10) add trust and literacy to this list of prerequisites. In this article we want to follow this line of thought and argue that (critical) literacy, but also reflexive agency, are conditions of possibility for participation.

This argument also extends to the past. Today's civil cultures, engagement and participation are being shaped not least by citizens' memories of their social practices, then and now. Critical literacy also requires developing critical reflections towards the past, identifying and articulating personal perspectives towards the propaganda and its effect on citizens. Reflecting, understanding 
and interpreting are elements of an ongoing process of comparing the past with the present. This also implies the need to investigate the relationship between the citizens' democratic competences in the present evaluation of media (in particular television) role and experiences of mediated participation in the past. But at the same time we should acknowledge the existence of critical media literacy during the Soviet era. Even though the Soviet system was based on propaganda, censorship and a ban of democratic participation, citizens developed critical approaches and modes of resistance towards the dominant ideological discourses. The main aim of this article is to explore the relationship between democratic participation and critical media literacy, that existed in Lithuania well before the democratic transition, in the late 1980s. Reconstructions of the individual strategies of using Soviet media in the past and comparing it to the present practices shed light on these critical media literacy skills, which we see as an important prerequisite for democratic and deliberative participation. An oral history approach has been selected to collect personal stories of the Soviet television media usage to show the existence of such skills.

\section{Participation and critical media literacy}

In order to understand the historical prerequisites of participation in the post-Soviet environment, we first need to deal with the complexity and variety of theoretical approaches of participation. Carpentier (2011) refers to participation, from a democratic theory perspective, as the inclusion of people into political decision-making processes. This is not a mere formal process, and more and more attention is given to the democratic cultures and practices besides the formal conception of democracy as the delegation of power to the others. Differences between the two understandings of democratic participation, namely minimalist and maximalist, are well defined by Carpentier (2011). The minimalist democratic participation model strongly emphasizes representation and the delegation of power. The main focus is on macro-level participation (national level of politics and political imagined communities) and popular will formation, which is built on consensus rather than multivocality, homogeneity rather than diversity. By contrast, in the maximalist democratic participation model, both macro and micro level participation forms are equally important for the promotion of citizens' active engagement into different levels of social life, including schools, family, workplace, church and community. 
These participatory processes also have a communicational dimension, as Habermas's (1989) work confirms. His articulation of deliberative democracy shows the importance of having decisions deliberated, discussed and clarified in the public sphere, which is to be open for everyone willing to engage into the debate via different forms of communication action. Apart from Habermasian deliberative democracy theory, Dewey's theory of participatory democracy, and the concepts of habitual and reflexive human agency (Wipple, 2005) also have relevance here. Habit and reflectivity are crucial components in Dewey's democratic and social theory. Reflective agency helps facilitate resistance to system-level manipulations and distortions by encouraging and empowering citizens. In his social theory, Bourdieu (1972) refers to historically and socially constructed habitus as a dynamic process constructed and actualized through available field and practices. In other words, habitus includes open, enduring and experience-based schemes of perception, classification and action (Bourdieu and Wacquant, 2003):

The structures constitutive of a particular type of environment (e.g. the material conditions of existence characteristic of a class condition) produce habitus, systems of durable, transposable dispositions, structured structures predisposed to function as structuring structures, that is, as principles of the generation and structuring of practices and representations which can be objectively "regulated" and "regular" without in any way being the product of obedience to rules, objectively adapted to their goals without presupposing a conscious aiming at ends or an express mastery of the operations necessary to attain them and, being all this, collectively orchestrated without being the product of the orchestrating action of a conductor. (Bourdieu, 1972: 72)

The relationship between habitus as socialized subjectivity (mundane, taken-for-granted individual structures) and the field as objective societal structures (such as social, political or media institutions) results in the particular formation of particular practices and representations such as adjustment, nonconformity, resistance and reconciliation (Bourdieu and Wacquant, 2003). However, as products of history and of the social, individuals are also active in shaping structural conditions and positions. For this, reflections on the existing dispositions and understanding of available positions are important for individuals to engage in the public discourse and action. Deconstruction 
of democratic or non-democratic schemes of perception, thought and action embodied in social norms and practices (i.e. habitus) is essential for participation in socio-political environment. The deconstruction of available habitus can be performed through reflexive agency with competences and skills of critical assessment of the present by remembering the past, which renders reflexive agency a condition for possibility of participation.

Participation then becomes understood as a discursive, reflective, and educational process, which is important as formal involvement in political processes (Dryzek, 1994). In this regard it is important to address critical thinking and (critical) media literacy as democratic practices, as well as imperatives for participation (Kellner and Share, 2007). For this reason, we want to argue that (critical) literacy (Turkoglu, 2011) is a prerequisite for participation. In communication and education policy documents, the notion of media literacy often refers to the individual competences to access the media, to understand and have a critical approach towards information and media power, and to communicate in different forms and contexts (Study on Assessment Criteria for Media Literacy Levels, 2009; Turkoglu, 2011). Three levels of communicative competences and skills are identified: (1) accessing and using different information sources, including official, mainstream, as well as alternative and public-generated media; (2) understanding and exploring the principles and techniques of media content production; (3) creating, participating and interacting in the media environment to practice one's democratic rights and responsibilities. Kellner and Share (2007) further expand the normative understanding of media literacy: they call for critical media literacy as a political project for democratic social change by emphasizing the need for enhancing critical analytical processes, challenging dominant ideologies and transforming society into less oppressive and more egalitarian democracy. They also identify a direct relationship between critical media literacy and participation, which is further elaborated by Türkoglu (2011). She points out that critical media literacy should be considered as a theoretical, interpretative and evaluative framework for participation of citizens through the media:

Critical media literacy also has a crucial role to play in offering interpretative and evaluative frameworks for understanding the possibilities and limits of the (allegedly) participatory process media organise, structuring the traces of power imbalances these mediated processes often contain. Both 
(home) audience members and (future) participants would highly benefit from an in-depth understanding of the wide range of participant management. (Türkoglu, 2011: 148)

At the same time, we should keep in mind that the conditions for participation, such as reflective agency and critical media literacy, can also exist outside a participatory and even democratic context. The existence of reflective agency and critical media literacy is not dependent upon this participatory or democratic context, but at the same time they can (at least potentially) become mobilized once a political community enters a more democratic context. Within the focus of our article, this implies that we can look at the role of critical media literacy skills in the Soviet past, and see how they pre-exist the transition to democracy. Moreover, the memories of how these critical media literacy skills were deployed in the Soviet past also plays a crucial role in contemporary Lithuania. Given that recollection of the Soviet past is shaped by socially constructed discourses, it is crucial to elaborate on the memory construction process in more detail. In the following section, the controversies of memory politics are discussed in view of the Soviet experience.

\section{Participation and democratization of memory}

For a democratic habitus to develop, exposure to different interpretations of the past is a crucial precondition. Memory is not merely an individual, but also a social construction. On the one hand, memory is a subjective reality, an intention of consciousness streamed towards a specific historical moment and personal experience. On the other hand, individual memory is never only personal, but immersed into a more general social configuration of memory; it is socially determined. The politics of memory adopted in different countries invokes different mnemonic strategies and uses relevant mnemonic practices and devices. Mnemonic devices include public spaces, streets, monuments, buildings, art, museums, commemoration activities like memorable days, images in public spaces, art and media. Memory cannot be imagined and embodied without the role of the media, which is seen as a key carrier of memory.

The politics of memory deals with institutional memory which, according to Richard Ned Lebow (2006), describes efforts by political elites, their supporters, and their opponents to construct meanings of the past and propagate 
them more widely or impose them on other members of society. However, it is important to understand that multiple memory discourses coexist in society in various degrees of correspondence, and they compete with each other. Institutional memory and discursive formation of the memory are by no means fully controlled and determining processes.

The politics of memory describes a process that involves large number of actors, some of them are private individuals, some government officials. These actors have access to a wide range of resources and mobilise them to achieve goals that may be discrete and quite diffusive. They act in political and cultural setting where other influences, many of them unpredictable and unforeseen, help shape the consequences of their behavior and the ways in which debates evolve. It is a complex and open-ended process may produce short- and long term outcomes at odds with expectations of key actors. (Lebow, 2006: 26)

Policies of memories often transform into memory games, when memory is instrumentalized to defend and construct certain group identity: "The concept of memory games encompasses the various ways by which political and social actors perceive and relate to certain historical events, according to identities they construct, the interests they defend and strategies they devise to define, maintain or improve their position in society" (Mink and Neumayer, 2013: 28). These games are played by institutional actors (e.g. parties, elected officials, governments), social movements and professional groups (e.g., historians, journalists). For the recognition of the diversity of interpretation of the past and potential memory formation in a democratic society, it is important that people have skills (and are helped to acquire them) to critically understand what is happening around them, understand and recognize which "memory games" are played, who the players of these games are, and how these games are played. Critical thinking and critical media literacy skills enable citizens to identify the ways memory games, their main actors and discourses, both dominant and alternative ones, are represented in the media, and to understand what communicative strategies, techniques and resources are used in dominant discourse constructions. When dealing with memory games, as well as memory wars, critical media literacy is a set of competences using a critical approach towards dominant discourses, tolerating diversity of opinions and mediated interpretations of the past. 
From the perspective of democratic participation culture and habitus, it is important that citizens understand discursive formations of memory; are able to identify what institutions and actors produce dominant discourses and what their relationship with individual memory is; are capable of differentiating between conflicting discursive practices and alternative discourses of memory; and can grasp social reality in the present and in the past as a complex phenomenon of contradictory nature. The social world is criss-crossed by ideological and sometimes even propagandistic projects striving to give meaning to past and present; thus it becomes crucial to understand the nature and specificity of these projects, how they are articulated, and how they are responded to, and how they are remembered.

In short, reflexive agency contributes to democracy (and participation) when citizens gain the ability and habitus to tolerate conflicting realities within society and are able to recognize different interpretations of the past, strategies and politics of memory. This also involves understanding one's own social identity in relation to memory politics. Following German historian Joern Ruesen's (2007) concept of historical consciousness, one of its core dimensions is critique. In a democratic society, the democratic attitude to memory processes should be promoted. The "democratization of the history" and the "democratization of memory" (Brüggemann and Kasekamp, 2008: 441) refer not only to the ability to critically reflect on complex and ambiguous historical events, but also to tolerate and accept alternative views of history, to understand the plurality of social memories which exist in each social setting. Thus, both, the critical thinking skills of citizens, and the state of historical consciousness, as well as sensitivity to otherness and openness to diversity of reality interpretations, enable the development of democratic citizenship. But, as we shall see, this critical reflexivity can also exist outside democracy, potentially opening up spaces for democracy within non-democratic settings.

In addition to critical thinking skills, critical media literacy enables the exploration of the role of media as carriers of memory in different memory politics. In the process of remembering the past, it is important to understand the power of media in representing democratic and undemocratic models of participation. Speaking of Soviet television, it is vital to understand the ways that Soviet propaganda was transmitted through the media and the effect such information had on the citizens, inhibiting their democratic habitus or, alter- 
natively, provoking their resistance to power holders and manipulation. Thus, critical media literacy, understood as the critical awareness of the ideological power of the media, is again an important component of democratic participation, and again it can pre-exist participation and democracy.

\section{Politics of memory and mnemonic strategies in Lithuania}

After the restoration of Lithuania's independence in 1990, the processes of building national identity intensified. Desovietization took place not only as the dismantling of institutional structures, but also as the transformation of the public sphere, communication and culture. Starting in early 1990s, streets, squares, and public spaces were renamed to eliminate Soviet semantics. All Soviet monuments were removed from public spaces.

Also at this time, Russian television broadcasts were reduced, the Lithuanian broadcasting sector became diversified in terms of new commercial channels introduced separately from the public service broadcaster with two national channels. New commercial television channels focused on popular local creative industries, as well as imported Western production, mainly films and television series (Pečiulis, 2000). Through derussification, the separation of the new cultural and political space from the entire geopolitical Russianspeaking former Soviet Union region was achieved. Along with reconstructing national identity, from the mid-1990s the aim was also to engender a European identity. In order to distance the public from certain layers of historical memory, a strategy of forgetting the past was actively applied. In terms of television programming, there was a clear decline in the representations of Soviet life and a withdrawal of Soviet production from the broadcasts, including films and broadcasts in Russian (Pečiulis, 2000). The systematic forgetting of traces of the Soviet era daily life style, pop culture, and media production, as well as avoiding any positive mention of this period was aimed at minimizing the effects of the Soviet regime's ideology as well as countering any nostalgic feelings of this past.

When discussing the politics of memory in Lithuania, and the public communication strategy towards the Soviet era, the analysis of the Lithuanian researcher Linara Dovydaityte (2010) on the role of museums as public communicative spaces in the politics of memory is of particular relevance. She reveals similar trends of keeping silence and excluding particular historical facts. The role of the museum as mnemonic device for the former Eastern bloc has been 
in line with the post-communist attempts to reaffirm national identity. The author argues that one of the challenges of constructing post-communist national identities is precisely the problem of dealing with the communist past and its placement in post-1989 memory politics. According to the author, most museums represent an uncomplicated anti-communist attitude to the past rather than the complex history of life under communism. The absence of the history of communism in museums is symptomatic of the post-communist culture of memory in Lithuania. The historical narrative is reduced to a story of communist crimes and victims, or incorporates a distancing of oneself from the communist past by turning it into an exotic story of the "other". Indeed, after 1989, the main events and topics of the past in Eastern Europe included, first of all, the history of resistance against the communist regime and a commemoration of the victims of the crimes of the Soviet regime. Memory politics in Lithuania ignores daily life under communism. Looking at the above-described politics of memory and certain processes of forgetting from the critical theory perspective, it should be admitted that such a selective memory strategy simplifies the past and thereby hinders the development of a critical relationship with the Soviet epoch. It limits the possibility to develop citizens' ability to critically evaluate the past by "weighing" all the arguments, to make informed judgments, to assess controversy, ambiguity and complexity of the history.

Avoiding this confrontation with the Soviet past through silencing, forgetting and exclusion in the Lithuanian politics of memory may trigger unexpected reactions. One of the most obvious consequences of forgetting the past is that such a subjective strategy impedes the understanding of present identities and habitus, which are rooted and embodied in the past. On the basis of these theoretical assumptions, in combination with the values of participation and democratization of memory, we have investigated the expressions of citizen's critical thinking skills and at the same time the manifestations of critical media literacy in the process of evaluation of the past - their experiences and accounts of the Soviet television. In the following section, first the research methodology, based on an oral history approach, and then the research sample are detailed.

\section{Research strategy and implementation}

In order to investigate the social construction of public communication and the critical responses it provoked within the memory space of Soviet television 
and post-Soviet period, we implemented audience research by carrying out oral history interviews. Memory is the main subject of oral history; it is considered to be an activity that gives meaning to the past through its reconstruction in narrative. The research has been carried out following methodological guidelines for oral history research (Ritchie, 2003, 2011). We use a critical theory approach in oral history, seeking to reveal critical readings of Soviet propaganda and alternative communicational practices in the past and the influence of memory politics in the recent present. The sample is composed of 163 interviews with people of different ages conducted in different areas of Lithuania. Individual accounts were collected by a group of trained students who were following interview guidelines and questions at Vytautas Magnus University (Kaunas, Lithuania) in April 2013. The main questions were related to the people's memories, experiences and opinions on the use, production, content of the Soviet television and its comparison with today's television. To preserve confidentiality of the recorded accounts, interviews have been anonymized. In asking our informants about their television practices in Soviet times we understand that their responses reflect not just their own memories of their relationship with the Soviet past. We realize that our study participants are the subjects (in Foucault's terms) affected by the dominant official discourses. We cannot deny that our informants in one way or another have been influenced by the Soviet propaganda and socialization system.

A request for the research participants to recall and evaluate Soviet television is an invitation to reflect on its potential impact on them as citizens, given the common socialization strategy (where television had its distinctive role), and official propaganda effect of the Soviet era. But at the same time these interviews show the resistance that the Soviet propaganda provoked. More particularly, we were searching for participants' evaluations of television under the communist regime with reference to critical thinking skills and critical media literacy competences - in relationship to the past and the role of media. Yet it should be noted that the informants' individual and historical memory (what and how they remember about the past) is affected by the politics of memory developed in Lithuania over the past decades and is shaped by the participants' socialization and social life. Individual memories are shaped in intersubjective spaces through interactions with others, and at the same time reflect dominant discourses in society. Thus, hypothetically we envisage that the way individu- 
als reconstruct and evaluate the past may build not only on their authentic lived individual experiences of the past, but also on different conflicting webs of memory and diverse vectors of evaluation of the past. While we understand that individual memory may be selective and can provide biased and inaccurate representations, we also realize that it relates to broader social and political processes in society. Hypothetically we can try to retrace national identity building and desovietization ideology with its corresponding politics of memory during the period of the recent 20 years that have been affecting representations of the past. We believe that such research represents not only our effort to understand some aspects of social reality, but also a kind of invitation to the research participants to engage into the critical discourse process and confront the Soviet past while taking into account its controversy, complexity and ambivalence.

Following an oral history approach to study media history, we are seeking to identify a set of configurations of individual and collective memories, which indirectly refer to the objective reality through the subjective reconstruction of the facts and events in the past. When questioning people about the past we reveal their memories and the ways the past experience is reflected and conceptualized. In the analysis of the research participants' stories on the memories and experiences of Soviet television, we tried to avoid naive explanations that suggest that people basically recall what was happening in the past, and the only distorting factor is natural oblivion caused by the passing of more than 20 years. On the one hand, we apply critical theory to address the potential impact of social structures and dominant discourses on the individual consciousness and possible individual memory formations in the context of different memory politics. On the other hand, the study is aimed at identifying the informants' perceived relationship with and their attitudes towards the dominant discourses of the time and any potential manipulation of the past and the present.

\section{Research findings: critical interpretations of the Soviet and contemporary media}

One major finding is that interviews with people of different generations reveal varying critical assessments of the Soviet television propaganda. Research participants underline television propaganda, one-sidedness, political engagement, exaltation of the Soviet reality. The main evening news programs, reiterated by the informants, included "Panorama" aired on the Lithuanian television 
and "Vremya", broadcasted on the Central television of the USSR, in Russian. Both were full of major events, achievements, and positive news from the entire Soviet Union. Communist party congresses, the five-year plans and their achievements, were part of the standardized daily coverage. Soviet propaganda eliminated any form of critique of the Soviet system and communist ideology, and therefore, no accidents, human losses, or social and environmental issues could be part of the news. The following extracts from the interviews articulate the role of propaganda in the Soviet television broadcastings:

The Soviet spirit was everywhere and every time. What kind of meaning had broadcasts of the Communist Party congresses that were broadcasted by all the channels and radio stations? None of the news program could avoid praising party leaders, downplaying capitalism and glorifying the socialist ideas. Even children's movies were about good policemen, who always help a person and so on. Well in general, it were broadcasts about life of those days, as well as the past imbued with the spirit of communism. Even in evening movies were usually some terrible nightmares of World War II, where heroic communist characters were fighting against bad fascists and perished before pronouncing that they serve their country, and the Communist Party.

Soviet propaganda on television is criticized by research participants for the inadequate depiction and falsification of reality, and for the lack of diversity and pluralism on television representations. Despite the officially represented picture of the Soviet life, people would identify the gap between depicted reality and the signs of everyday life. Particularly relevant here is that the critical readings, based on the confrontation of different knowledge systems, are themselves situated in the past, and are not articulated as an interpretation that was only added at a later stage.

For instance, it was published that there were no deaths in the Afghanistan war, even though everyone knew about the returning galvanized steel coffins.

Exaltation of the Soviet reality is perceived as an outcome of a wide censorship that affected almost all spheres of public life, as well as falsification used for propaganda purposes. For instance, positive reporting on the Soviet Union is usually contrasted with the critique or silencing of the Western society. People would learn about the poor life of the workers in the West, their strikes, 
accidents, social issues. Critical accounts of the Soviet propaganda are often followed by ridicule and irony rather than condemnation:

... all shows and concerts, and some kind of information programs were more of a propaganda nature, that we have a very good life here, that we produce a lot: harvesting a lot of potatoes, producing a lot of sugar, and that, say, we are the best and, well, only positive to say it again. If there were any news from abroad, it was just that foreign countries were too bad, the West was a "rotten" West. We were pumped by this information, and we, of course, holy believed in that.

Broadcasts of the major ideological celebrations were an important part of the Soviet propaganda. May $1^{\text {st }}$ - Labour day of human solidarity, November $7^{\text {th }}$ - October Revolution Day with a gala parade broadcasted live from Vilnius or Moscow, May $9^{\text {th }}$ - Victory Day with the live broadcast of the military parade in Moscow. Apart from the annual celebrations and demonstrations, there were other events that would make citizens be proud of the Soviet regime, e.g. the $1^{\text {st }}$ human spaceflight by Gagarin, the Moscow Olympics in 1980, etc. These citations also illustrate the seductive and mobilizing strength of these representations, and here we see the distancing critical operation taking place ex-post.

Of course, television shows reflected the ideology of those times. I remember the slogans of the five-year plan achievement within four years, about labour gifts for any party or Komsomol Congress, Stakhanovites' work. Congresses and plenums were continuously broadcasted, the communist worldview installed into the viewers' consciousness. I remember May 1'st, Victory Day, the October Revolution, the demonstrations, the atmosphere-party leaders worships, thunderous "Ura", party leaders portraits, flags, slogans.

Well, everything was fine: we go forward, we implement plans and we have the best athletes, the best culture professionals. We felt that here, wow, we can conquer the whole world.

When invited to evaluate Soviet television, informants would emphasize that they were missing diversity, pluralism, also Western movies; the Russian ones were seen as having a very clear ideological discourse on class struggle between the bourgeoisie and the poor: "Soviet television - restricted, censored, and predictable". 
In the Soviet times, those who were not interested in politics and swam downstream, television would provide some kind of information and entertainment. For those interested in politics and foreign life, information was only one-sided. So television acted as a propaganda tool and a source of entertainment.

The reconstruction of the Soviet television also reflects clear signs of conflicting processes of identity construction, which again show the critical actions and readings of the research participants. In their narratives we recognize tensions between identity constructs created by the mediated Soviet ideology and national identity construction processes in the past and in the present. In other words, the relationship between memory and national identity construction processes, as well as the role of media (Soviet television) are vital in construction of identity. In the Soviet Union one of the political goals was to develop existing nationalities into a united new nation, the Soviet people (sovetskij narod) as a supra-nationality. There was the ambition to establish a new human community, sharing a common territory, state, economic system, and culture, striving to build communism and a common language (Grenoble, 2003). Specific language policy was employed for this goal. It sought to make Russian the common international language - lingua franca - for the emerging supra-nation. Using policies of bilingualism and russification, Russian was promoted as a "second mother tongue" in many Soviet republics and regions. This language policy was developed through the school curriculum and media (television and cinema). In 1989 fluent knowledge of Russian among ethnic Lithuanians was 37.4 percents (compared to ethnic Estonians in Estonia - 33.6 percents; ethnic Latvians in Latvia - 65.7 percents; ethnic Kazakhs in Kazakhstan -62.8 percents) (Dietrich, 2005).

In Lithuania there was opposition to the language policy of russification. That is why, when recounting of television content in the Soviet times, informants identify the relationship and confrontation between two different social identity construction processes - one constructed by the contents of the Moscow broadcasts (mainly Russian) and the Lithuanian identity constructed by the national Lithuanian television. First of all, many people recall that Lithuanian television production had limited live broadcasts, and was of poor quality and rather boring, while Russian television channels had longer airtime and offered a larger choice in terms of different educational and entertainment programs. Nonetheless, local language and ethnic culture were strongly supported 
and appreciated by our research participants. An example of the confrontation of the two identities was sports and basketball in particular. Informants remember watching a basketball game between the Soviet team "CSKA" and the Lithuanian team "Žalgiris" as watching a struggle between two countries, different cultures and identities. The "Žalgiris" victory meant not only winning a sports competition, but also some kind of resistance to the Soviet ideology. The research participants remember mainly the Lithuanian broadcasts, television anchors and actors, and almost do not mention non-Lithuanian hosts and actors who appeared on the Moscow television broadcasted in Russian. This reveals how important the role of the Lithuanian television was in resisting the russification policy at that time.

When remembering the past the research participants also highlight the role of alternative media resources, which emphasizes their critical resistance even more. In the Soviet system, the official media were strongly controlled by the state apparatus seeking to shape a loyal, obedient and passive media consumer. On the other hand, such a strong censorship encouraged active resistance against power structures and the development of alternative media consumption, including local underground press and foreign media channels. In order to fill the information gap and have access to more diverse representations of the Soviet and Western world, people used alternative media sources, such as the radio channels "Voice of America", "Radio Free Europe", and the Polish television channels. This made a huge difference in the content and the scope of information received. For instance, Western movies, pop music, the Pope's visit to Poland, the Solidarność movement, and the strikes of the workers in Gdansk were only visible on the Polish television channel, which was available in the border areas of Lithuania and provided the viewers with a more open window to the world. As illegal, but widely used media content, Polish television, as well as other foreign media use became some kind of silent resistance and rebellion against the official order. These memories and recognition of the role of alternative resources are again signs of critical media literacy. Citizens perceive the significance of resistance against the authoritarian regime through access and use of alternative means and resources of communication.

The critical mode was not the exclusive and dominant one used in describing media practices from the Soviet past. The research also showed the presence of a nostalgia towards the past, the limits of propaganda critique and a certain 
lack of critical media skills while remembering and reconstructing lived experiences of childhood. Life stories, recalled by the participants, reveal people's childhoods, youth and professional careers in the Soviet period, in relationship to their media use and practices. It appears that television accounted for only a small part of the everyday world. Many other things were important, but also other media were important, in particular national and regional newspapers, specialized magazines for women, youth and children, science, culture, literature. For children, there was a half-an-hour daily children's program and special weekend programs for children and youth. Television still had its definite place in the general daily routine - for decades children's programs broadcasted at the same time with the same hosts created a sense of stability and sustainability. Though television played a minor role in terms of weekly hours in young people's lives, we find a more general description of what their childhood and daily routine was - school, playing games, non-formal educational and sports activities, reading books, and so forth. We find a very clear separation between the worlds of children and parents-adults in terms of television. Our informants state that at their young age they were interested in watching children's cartoons, children's movies, while their parents looked for political information programs and entertainment. People's childhood experiences are described with certain nostalgia, which usually takes place when people are telling about their childhood, parents' family and other early memories. At the same time, in this existential childhood nostalgia we can also recognize some kind of political nostalgia. Our informants are missing the Soviet mass mediated images of the world. The vast majority of informants are sentimental and nostalgic about the ideal social world constructed by the television - a world without poverty, injustice, disasters, crimes, violence or profanity.

One of the main themes of the Soviet television that the research participants focus on a lot is animation. It is not surprising that this theme dominates the narrative - the majority of our research participants were children in the Soviet times. Therefore, Soviet cartoons are among the most distinct childhood memories. Recalling and reflecting on childhood opens the door to the people's lived world with the heroes from the tales - hares, bears, wolfs, foxes, good and bad characters, representing a moral struggle between good and evil. On the other hand, as stated by the Soviet propaganda researcher Gintautas Mažeikis (2010), propaganda concealed an important area of ideological persuasion in 
animation. Propaganda in animation prepared children for future more serious persuasion campaigns. Subject formation via persuasion and propaganda took place in hidden ways through attractive forms, with pleasure and charm. Many hidden curriculum items were used. According to Mažeikis (2010), there were several types of animation: first, those with open models of heroic class behaviour, and secondly the covert way to represent classes and political figures in the form of animals, Cinderella, little shepherds, and so on. In a metaphorical form, animated characters represented the class struggle as the struggle between the good and the evil. However, the majority of the informants did not identify propaganda content in the children's cartoons, on the contrary, they felt nostalgic about their positive nature, and consider them as a merit of Soviet television and society. This inability to recognize propaganda within children's cartoons is an indication of its success

Finally, the research also reveals interconnections between the critical evaluations of the past and present. Participants demonstrate critical media literacy while evaluating the media of today and expressing their critique of the contemporary media landscape. Remembering the past allows individuals not only to retrace memories on past experiences, but also to negotiate daily contemporary practices. Pluralism and the abolishment of censorship are among the most frequently mentioned positive aspects in regard to contemporary television. However, our research participants share lots of criticism towards current television production and its content. Anger, violence, aggression, polarization, bad taste, poor language, lack of quality standards, as well as lack of decent, respectful attitude towards human dignity, all illustrate people's disappointment. The research participants argue that most entertainment programs and shows are market-oriented products created to attract audiences and usually have no long-term value. In the context of dominant negative discourses about television, people express some kind of longing for Soviet television, as well as for the Soviet epoch, when television and media generally were more positive and tried to calm and educate people rather than frighten and humiliate them. Thus, people experience two types of transformations: on the one hand, the political and economic systems have changed, while on the other hand, there has been a clear shift in cultural policy, one that can be described as moving from modernism towards postmodernism. 
Indeed we grew up in that culture rather than the Western culture, and sometimes for us what you do not understand now - some sort of humor, those hints we actually understand better. And sometimes you stop at the channel that is showing an old movie, which has been precious to you, interesting, or there is a really talented and fun actor, or some kind of comedy which has become classic. I watch the actors that have already become classic, some of them no longer alive. You stop and remember how it was actually. Never, at no time, it was just bad, and when today some people are erasing those days because of the Soviet times, it gets sometimes disgusting and I feel bad, because we simply do not have the right to ignore the people who were created in those days.

It can be said that when criticizing the current "trash-television" and entertainment industry, as well as comparing it to the already described and more positively remembered Soviet television (and the Soviet cultural policy), they clearly express a cultural criticism of the postmodern capitalist society. This criticism in principle (in its main intention) coincides with the one described by a number of critical theory authors (e.g. the Frankfurt School, Jean Baudrillard, Guy Debord). In the narratives of the research participants on television, there is a strong critical element towards consumer society, commodity fetishism, flatness and vanity, immorality, promotion of bad feelings and instincts, lack of intellectual and analytical activities.

Some evaluations of the past also demonstrate a moderate critique of existing politics of memory in Lithuania. As discussed above, two main trajectories of memory politics can be identified. First we have the dominant national identity discourse, promoting desovietization and derussification. Secondly, there is the dominant discourse as manifested through the condemnation of the Soviet past, which are silencing and forgetting strategies. Meanwhile, research participants distinguish positive features of the Soviet television that they miss in modern television. They stress high culture traits that were exhibited in the Soviet era - intellectual and educational content, including programs about science, travel, animals, analytical programs about politics. The research participants praise the clear moral values represented in good quality films and animation, mentioning also the romanticism and sincerity of feature films, and movie production of high aesthetic quality, such as by Tarkovsky. These expressed positive assessments of the Soviet television, on the one hand, are indirect confirmations that the Soviet regime was based on a clear and strongly regulated 
cultural policy (in particular through censorship). In order to put those ideals into practice, moral ideals are emphasized, good against evil prevails, and high art is considered as the outstanding Soviet culture and a way of life. However, here we also notice some kind of nostalgia for ideals in the modern times - a clear divide between good and evil, high culture and arts, one dominant discourse and narrative, rather than several competing ones. The fact that people develop positive discourses of the Soviet ideology may also demonstrate some kind of critical thinking, as one understands that talking positively and being nostalgic of the Soviet era is deviating from the dominant discourse in Lithuania for the last 20 years of policy criticizing the Soviet past.

\section{Discussion and conclusions}

Before, we mentioned the idea that the lack of sustainability of democratic habitus and fragility of democratic participation in the post-Soviet society are both linked to the history of having been part of an authoritarian regime and its paternalistic culture. However, the empirical research shows that citizens express a well-defined critique of the power manipulation and propaganda persuasion in the Soviet media. When assessing Soviet television, research participants provide clear identifications and articulations of the Soviet television propaganda that citizens were exposed to - research participants identify in detail visual images, strategies, methods, techniques of the propaganda effect. They point out such traits of the Soviet television as the glorification of the Soviet society achievements, the politicization of television content, the one-sidedness of news coverage, including positive images of the Soviet regime, the silencing of critical issues, and the criticism of the "rotten" West and capitalist society. Our research participants demonstrate skills of critical thinking by revealing their perception of the relationship between power, dominant discourses and affected citizens. They understand the nature and mechanisms of propaganda persuasion in the non-democratic state machinery. At the same time, critical evaluations are a feature of collective subjectivity, a result of both the silent resistance in the Soviet times and the official criticism of the Soviet regime in the public sphere since the beginning of 1990s. Informants acknowledge that they - to some extent - may have been affected by the Soviet propaganda discourse, however their expressed criticism of the propaganda and personal encounter with the Soviet propaganda machine discourses, as well as their reconstruction 
of their experience, imply that we are dealing with a critical literacy practice, which we see as a condition for democratic participation.

By recalling and evaluating the past, the audiences in the dispositions they cultivate towards the media manifest not only a form of general critical thinking skills, but also enact critical media literacy. In the memories about the Soviet television, we can acknowledge audience competences to critically analyze, process and understand the principles and techniques of media content production, and their abilities to access and use different information sources, including alternative media. Our research participants also emphasized their understanding of how alternative tools operated. The analysis demonstrates the role of Western channels programming as an important alternative information tool and education strategy.

It can be seen that in reconstruction of the past, the process of remembering may easily transform into a critical analysis of the present. In such a way we see that the past, the present and the future are interrelated in the citizens' historical consciousness and memory. The criticism of contemporary television is an indication of citizens' moral values, critical stance, and their aesthetic dissociation from unacceptable content. We cannot deny that such neo-Marxist critique of the capitalist society's cultural production does not have certain roots in the previous civic indoctrination, which was carried out during the Soviet era. In other words, citizens developed a certain habitus to recognize and criticize the capitalist and decadent, bourgeois West, with its culture and life styles. Despite this fact, the cultural critique of modern society (distinguishing the positive and negative aspects) shows again the capacity for critical media literacy, which supports their democratic citizenship.

The analysis confirms our assumption about the relationship between memory practices revealed through the oral history approach, and the conditions for participation (such as reflexive agency and critical thinking), as well as the role of discourse in shaping subjects through propaganda, persuasion and different politics of memory. Media, and especially television, play an important role in this process. The informants' critical assessments regarding the Soviet past and their relationship with it indicates that civic engagement takes place not only through transformations of the subject shaped by propaganda and persuasion technologies, but also through resistance to the dominant discourses of memory and communication distortions. The research findings also illuminate 
ongoing memory games and memory battles in the democratic society outside and inside different social groups, as well as on the level of individual lifeworlds. It requires significant efforts to reconcile the different memories and conflicting experiences by critically reviewing the past and the present. Such intellectual and emotional experience of openness to diversity becomes an important prerequisite of democratic participation. The positive treatment of certain aspects of the Soviet past and the willingness to disclose it reveal some kind of resistance to the dominant discourse and prevailing mnemonic strategies to portray the Soviet period as purely negative experience and to remove it from the individual and collective memory. Such a position shows a tendency of citizens to democratize memory, to practice the multivocality of memory, and to sustain the heterogeneity and diversity of interpretations of the past.

However, the study also shows the obvious, namely that to exercise one's democratic rights and responsibilities by genuinely participating, interacting and creating in the Soviet media environment was rarely done, and if it was, the risks were considerable. Apart from reflexive agency, the most active phase of the media literacy (the communicative action itself) is underrepresented in the public accounts of the past, but also in those of the present. Challenging dominant discourses and transforming social practices in the Habermasian sense of communicative action are weak. Nonetheless, the critical media literacy skills identified in the research study are still an important prerequisite for democratic participation, even if they only cover the first stages of participation in post-Soviet Lithuania - perception and criticism. 


\section{References}

Balčytienè, A. (2006). Mass media in Lithuania: Changes, development and journalism culture. European journalism review series 8. Berlin, Vistas

Balčytienė, A. \& Juraité, K. (2009). Impact of economic and cultural factors on television production in small nations. Medijska istraživanja / Media research, 15(2), 33-47.

Bourdieu, P. (1972). Outline of a theory of practice. Cambridge: Cambridge University Press.

Bourdieu, P. \& Wacquant, L. (2003). Ivadas ị refleksyviq sociologija [Introduction to reflexive sociology]. Vilnius: Baltos Lankos.

Brüggemann, K. \& Kasekamp, A. (2008). The politics of history and the 'War of Monuments' in Estonia. Nationalities papers, 36(3), pp. 425-448.

Carpentier, N. (2011). Media and participation: A site of ideological-democratic struggle. Bristol: Intellect.

Carpentier, N., Schrøder, K. \& Hallett, L. (2014). Audience / society transformations. In Carpentier, N. Schrøder, K. \& Hallett, L. (eds.), Audience transformations. Shifting audience positions in late modernity. London: Routledge, pp. 1-11.

Dahlgren, P. (2009). Media and political engagement. New York: Cambridge University Press.

Dietrich, A. P. (2005). Language policy and the status of Russian in the Soviet Union and the successor states outside the Russian Federation. Australian Slavonic and East European Studies, 19(1-2), 1-27.

Dovydaityte, L. (2010). Which communism to bring to the museum? A case of memory politics in Lithuania. Meno istorija ir kritika [Art history \& criticism 6] Special Issue: Istorijos (re)konstrukcijos nuo 1945-uju iki dabar [Performing history from 1945 to the present]. Kaunas: Vytauto Didžiojo universiteto leidykla, 6, 80-87.

Dryzek, J. (1994). Discursive democracy: Politics, policy, and political science. Cambridge: Cambridge University Press. 
European Commission (2013). Europeans' engagement in participatory democracy: Report. Flash Eurobarometer 373. Accessed 10. 10. 2013. URL: http://ec.europa.eu/public_opinion/flash/fl_373_en.pdf.

Grenoble, L.A. (2003). Language policy in the Soviet Union. Dordrecht: Kluwer Academic Publishers.

Habermas, J. (1989). The structural transformation of the public sphere. Cambridge: Polity Press.

Hoyer, S., Lauk, E. \& Vihalemm, P. (eds.). (1993). Towards a civic society: The Baltic media's long road to freedom. Tartu, Estonia: Baltic Association for Media Research.

Juraite, K. (2008). Media power in the Lithuanian news market reconsidered. Informacijos mokslai [Information Sciences], 47, 121-132.

Kellner, D. \& Share, J. (2007). Critical media literacy is not an option. Learning inquiry, 1(1), 59-69.

Lebow, R. N. (2006). The memory of politics in postwar Europe. In Lebow R. N., Kansteiner W. \& Fogu C. (eds.), The politics of memory in postwar Europe. Durham: Duke University Press, pp. 1-39.

Mažeikis, G. (2010). Propaganda ir simbolinis mastymas [Propaganda and symbolic thinking]. Kaunas: Vytauto Didžiojo universiteto leidykla.

McNair, B. (1991). Glastnost, perestroika and the Soviet media. London, New York: Routledge.

Mink, G. \& Neumayer, L. (2013). Introduction. In Mink G. \& Neumayer, L. (eds.), History, memory and politics in Central and Eastern Europe. Memory games. New York: Palgrave Macmillan, pp. 1-22.

Papacharissi, Z. (2002). The virtual sphere: The internet as a public sphere. New Media \& Society, 4(1), 9-27.

Pečiulis, Ž. (2000). Televizijos programų plètra [Development of television programmes]. In Divonaitè, D. \& Urbonas, V. (eds.), Naujosios žiniasklaidos formavimasis Lietuvoje [Development of new media in Lithuania]. Vilnius: Institute of Journalism, pp. 232-254.

Ritchie, D. A. (2003). Doing oral history: A practical guide. Oxford University Press. 
Ritchie, D. A. (ed.) (2011). The Oxford handbook of oral history. Oxford: Oxford University Press.

Rose, R. (2009). Understanding post-communist transformations: A bottom up approach. London, New York: Routledge.

Ruesen, J. (2007). Istorika. Istorijos darbu rinktine [Historicism. Collection of history writings]. Vilnius: Margi raštai.

Shudson, M. (2003). Sociology of news. New York: W.W. Norton.

Study on assessment criteria for media literacy levels 2009 (2009). Final Report edited by EAVI for the European Commission p. 2/92. Brussels.

Türkoglu, N. (2011). Mediated public voices need theory to be heard. CM: Communication management quarterly: Časopis za upravljanje komuniciranjem, 6(21), 141-158.

Verdery, K. (2002). Theorizing socialism: A prologue to the "transition". In Vincent, J. (ed.), Anthropology of politics: A reader in ethnography, theory, and critique. Oxford: Blackwell, pp. 419-436.

Wipple, M. (2005). The Dewey-Lippmann debate today: Communication distortions, reflective agency, and participatory democracy. Sociological theory, 23(2), 156-178. 